always attracted the interest of scientific workers in the dyeing industry. This is the specification of shades and the control of the dyeing process by means of the colorimeter, a process which, up to the present, has required almost complete reliance upon direct visual judgment. It was shown that patterns dyed with comparatively simple mixtures of dyes can be analysed colorimetrically with sufficient accuracy to allow matching dyeings to be produced solely on the data thereby furnished. Technically, this is a very considerable achievement, and although the method is not yet ready for general introduction into the dye-house, the beginning thus made is extremely promising. If instrumental patterning becomes possible, the next step may be automatic control of the course of the dyeing operation, and the dyer's Utopia will be in sight.

Apart from the very pleasant social atmosphere which marked the whole of the symposium, encouraged by the excellence of its management and the character of the discussions, one further item must be mentioned as contributing very markedly to the general success. This was the readiness of some of the larger firms concerned with the textile industry to allow their research staffs to make serious and extensive contributions from the results of work carried out in their laboratories. This attitude, so important for general progress, has not always been so much in evidence, nor is it yet universal. The chief guest at the Society's dinner was Mr. A. H. Wilson, recently University lecturer in mathernatics at Cambridge, who, after a distinguished career in the field of pure science, now holds an important administrative position in the industry as director of research and development of Messrs. Courtaulds, Ltd. ; his considered compliments on the scientifie activities of the Society of Dyers and Colourists will be a source of great encouragement.

H. A. TURNER

\section{HOW FAR CAN BRITAIN FEED HERSELF?}

$\mathrm{T}$ HE Nutrition Society, at a whole-day conference held on October 25 at the London School of Hygiene, discussed "British Needs and Resources of Calories, Protein and Calcium". The Right Hon. Walter Elliott was in the chair.

The conference was planned some months ago, before the food situation became so threatening. In the first place, nutritionists were asked to give their considered opinion as to what amounts of food were needed in the United Kingdom to meet adequately the whole physiological needs of the human population, having regard to the dietetic habits of the British when unhampered by rationing. In the second place, a number of agricultural and fishery authorities, having been given a preview of the nutritionists' requirements, were invited to say how far British food resources could reasonably be developed to meet these requirements. The present alarming situation, when even minimal nutritional needs, despite the utmost austerity of rationing, are far from secure, was unforeseen when the conference was planned, but lent a sombre interest to the proceedings. One of the speakers remarked that though it was not on the agdnda of the conference, an important and urgent question for discussion in the near future should be what we could do, having the new stringencies in mind, to meet from the agricultural and nutritional points of view a situation in which home production of food plus what Britain could buy with her failing credit from overseas threatened to be not merely below reasonable physiological needs, but even below minimal nutritional requirements for health and work.

In the first paper, Dr. E. R. Bransby, Dr. H. E. Magee, Mrs. M. C. Bowley and Miss B. R. Stanton gave a careful estimate, on the basis of the needs of the various age-groups in the population, of the amounts of different foods required to meet the requirements for calories, proteins and calcium of the whole population of the United Kingdom, both at the 1946 population of 48 million, and at the estimated 1964 population of 50 million (which would have a different age-group composition). They calculated these requirements on the amounts of food needed to enter the retail stage of distribution, not those actually eaten. The calories entering the retail stage are, in fact, some 10-15 per cent higher than those actually consumed, as determined by careful nutritional surveys - a gap for which, as yet, there is no adequate explanation.

The changes between the requirements as stated by Bransby et al. and actual pro-war supplies entail an increase of 48 per cent in milk and dairy products, of 56 per cent in potatoes and of 27 per cent in vegetables. Sugar needs are, however, below the pre-war level by 14 per cent, and the needs for fruit, fats, grain, meat, pork and eggs about the same as the pre-war level. It was stated that the diets as given provide not only all the physiological requirements for calories, proteins and calcium, but also those for all the other known nutrients. As regards protein, though for most age-groups more than half the total requirements were provided by animal protein, the authors thought that no clear evidence exists as yet as to what is the optimal amount of animal protein needed for a human dietary at different ages.

The discussion on the estimates given by Bransby et al. was opened by Mr. F. le Gros Clark. He doubted whether the menus which the first speakers had tabulated were really typical for those of the majority of the population of Great Britain. A good deal of our animal protein comes at present, and will continue to come, from milk, and he considered that the milk products/meat ratio should be increased. In estimating future requirements for the different types and qualities of food it is, of course, necessary to assume that the present relative prices will be maintained; but nevertheless, over even a short period of years, changes would undoubtedly take place which would greatly affect the demand for, and the consumption of, many items in the diet. In absence of rationing, and in view of the probable continuance of a high rate of employment and of wages, and of increasing education of the public in nutritional matters, he considered that it is highly probable that the demand for some of the more nutritious and tasty foods would exceed the needs as given in the first paper.

Prof. John Beattie mentioned experimental work on the calorie requirements of German prisoners under sedentary and under physically more strenuous conditions. It was found that, after loss of weight on a meagre diet, an immediate rise in food intake does not permit of increased expenditure of working onergy until after a lag period, during which the lost reserves are being built up again. His view was that the adult male age-group should receive an 
average of 3,500 calories, rather than the 3,000 that Bransby et al. considered sufficient.

Dr. E. C. Owen pointed out that the basis for the figures usually accepted for calcium requirements is not very secure. Individual requirements vary greatly. For various reasons, old people often get less calcium than they need. As regards the virtues of animal as compared with vegetable protein, he considered that the main factor is lysine, the irreplaceable amino-acid present in reasonable quantities in most animal proteins, but found to a much smaller extent in vegetable protein.

Dr. Isabella Leitch was dubious as to the basis of some of the previous estimates of food requirements. The right method is to draw up adequate menus for the whole population, and calculate total food needs on that basis. She could offer no satisfactory explanation of the gap of 10 per cent or more between 'food entering retail consumption' and that actually consumed in the house. This apparent wastage, however, varies greatly from one food to another. In the case of milk it is small. In estimating ealorie requirements for the adult working population, little more than a guided guess is at present possible, since the actual physical work done is so difficult of assessment.

If the gap between the estimate of food production plus imports and actual food consumption were as small as 10 per cent, Prof. J. R. Marrack thought that those making this estimate were to be congratu. lated. His view was that the average calorie requirement of adult male sedentary workers was usually appraised at too high a figure.

Dr. Wood suggested that three tables of food needs might be prepared: (1) the minimum nutritional requirements for health; (2) the requirements from the popular point of view, where items like sugar would be high; (3) the requirements if food were given away free.

In replying to these comments, Dr. Bransby stated that the diets suggested by himself and his colleagues were intended to be appreciably above the minima, and, in fact, at the 'comfort' level.

The first paper to approach the question as to how far the nutritionists' requirements could be met from home production was given by Dr. E. T. Jones, who dealt with wheat, potatoes and sugar-beet. $\mathrm{He}$ considered that by increased efficiency and more intensive management, yields per acre of wheat and sugar-beet could be fairly rapidly increased to provide from home sources fully 50 per cent of the total needs of Britain for bread grains and sugar. Such an increase would depend on the liberation of more than 680,000 acres from potato production. This could be achieved, and our potato crop still meet national requirements, if cultural technique were improved, by the application of existing knowledge, to give an average yield of 10 tons of potatoes per acre.

In the second paper, dealing with home production of milk and dairy products, Prof. H. D. Kay stated that to satisfy the nutritional requirements of Britain for liquid milk alone would entail an increase of about 25 per cent above our present annual total of some 1,360 million gallons of milk leaving the farm. $\mathrm{He}$ considered that, without any increase either in numbers or quality of our existing dairy cattle, a 10 per cent increase in milk coming off farms could be achieved if 400,000 tons of concentrated feeding stuffs, in addition to the quantity grown or imported at present, could be provided. This represents only
6 per cent of our pre-war total import of concentrates. The remaining increase of about another 15 per cent in the milk coming off farms could be attained by improving the genetic quality of the dairy cowsbut without any increase in their present numbers-by artificial insemination from bulls of the quality now in use in cattle-breeding centres. At present rates of progress in the development of artificial insemination, this would take some ten years. Additional feeding-stuffs. would, of course, be needed pari passu with the increase in potential milk-yields of the improved stock. He also emphasized that the technical skill both of the dairy farmer and his cowman would have to increase at the same time as his stock was improved, if full use was to be made of the effect of artificial insemination from high-class bulls.

Dr. J. Hammond discussed the difficult question of increasing the home production of meat (beef, mutton and pig meat) despite the simultaneous demands for home-produced and imported feedingstuffs which increased milk production and egg and poultry production would make. The total needs of meat, according to the nutritionists' requirements, are some $146 \mathrm{lb}$. per person per annum, of which only $38 \mathrm{lb}$. is at present produced in Great Britain. More beef might be produced at home by using good beef bulls, kept at artificial insemination centres, on the poorer milk-producing cows, to give colourmarked progeny that would not be mistaken for dairy animals. More winter feed for both beef cattle and sheep would be needed if meat production were to increase. As regards pig meat, any large increase would depend almost entirely on a rise in the supply of feeding-grain from abroad, though something could be done if more farms kept a few extra pigs which might act as scavengers and need relatively little food from outside the farm.

The possibility of increased fish supplies was considered by Mr. R. J. H. Beverton and Mr. G. C. Trout. The danger of over-fishing the North Sea was pointed out. It is considered that increased supplies of cod and other fish could be obtained from more distant fishing grounds, but this might entail the use of factory ships, since storage difficulties on the ocean-going trawlers are very great. As regards herring, there is no evidence whatever of an approach to the stage of depletion of reserves-many more could undoubtedly be caught fairly close to the British Isles. Here the difficulty is to dispose of the catches obtained in the peak period, by suitable methods of preservation. Increase of supplies of fish other than the herring undoubtedly lies in the exploitation of the more distant fishing grounds, and a 40 per cent increase in supplies is a possible attainment in a few years.

Egg production was discussed by Mr. E. T. Halnan. If larger quantities of suitable feeding-stuffs could be provided, he foresaw little difficulty in producing the increase of some 6,000 million eggs called for by the nutritionists. But with the greatest possible production of wheat and barley at home, and with a change in the rate of extraction of flour from the present 85 per cent down to the pre-war 70 per centneither of which seems likely-at least 368,000 tons of imported feeding-stuffs would be needed. From the figures he gave for present egg production, it appears that an unduly large number of eggs, apart from those legitimately produced by the 'backyard poultry keeper', are evading the official rationed channel at present. 
The general discussion was opened by Dr. W. K. Slater. He emphasized that the additional production of food from sources in Great Britain means increased supplies of materials, for example, for additional factories and plant for extracting sugar-beet and for housing poultry. The training of the human element in more efficient methods of cultivation and of management of stock is likely to be a formidable task. He asked whether a true appreciation of the immediate future position in Great Britain is rather that the number of calories per person and the nutritional value of the average diet generally are much more likely to fall than to rise; and how far this fall could go without acute sequelæ.

Dr. N. C. Wright considered that a matter of immediate importance is the prevention of wastage, from whatever cause, of food already produced. We must find out, for example, exactly what happens to the 10-15 per cent of calories that vanish as between food 'moving into consumption' and food actually consumed in the household. He believed there is no escape from a greatly increased importation of animal feeding-stuffs from overseas if home-produced human food is to increase.

The importance of disease control and the part that the veterinary profession could play in preventing wastage were emphasized by Dr. W. R. Wooldridge. Prof. J. R. Marrack inquired whether, if the amount of milk required per head per day by the nutritionists has to be produced as liquid milk during the winter months, it would not thereby entail a considerable excess to liquid requirements at the production peak during spring and summer, which excess could provide a substantial quantity of dairy products.

Prof. A. W. Ashby, in summing up, said that we should face the fact that the standards in Great Britain for human food have been reduced to, and are likely to remain for some time, those of a rather poor peasant population. $\mathrm{He}_{e}$ considered that more co-ordinated consultation between the experts in nutrition and in food production and the administrative authorities is needed to give a sound basis both for the planning of increased food production at home and the carrying of these plans into effect. $\mathrm{He}$ criticized some of the figures given by those who had spoken during the conference on the possibilities of increased agricultural production, and thought that more statistical wisdom and mutual consultation might have made their estimates more helpful. He was very doubtful whether the yields per acre of wheat, etc., that one of the speakers had assumed as attainable in the near future, could, in fact, be reached. Competing requirements for feeding-stuffs to provide milk, meat and eggs have to be regarded from the point of view of efficiency of conversion of feeding-stuffs to human foods. Here the dairy cow is far superior to the bullock. He emphasized that under an effective system of price control the relative prices offered to the producer for the different farm products is the main directive factor in influencing relative volumes of farm output.

The chairman, in conclusion, mentioned the surprisingly large total tonnage, relative to the tonnage of human food, that is needed to feed the animal population of Great Britain, and emphasized the importance and economy of producing the maximum quantity of feeding-stuffs at home by the intensive application of existing knowledge.

The proceedings of the conference will be published in an early number of the British Journal of Nutrition.

\section{OBITUARIES}

\section{Prof. J. Masson Gulland, F.R.S.}

IT was with a sense of severe personal loss that his many friends learned of the untimely death of Prof. J. M. Gulland, who was a victim of the railway accident at Goswick on October 26. He was a leading figure in the chemical world, a pioneer worker in several important fields of organic chemistry and biochemistry, and a man of outstanding personal charm.

John Masson Gulland was born in Edinburgh in 1898 and was the only son of the late Prof. G. Lovell Gulland, professor of medicine in the University of Edinburgh. Gulland was much devoted to his native land, and above all to his native eity, which he frequently visited. He was educated at Edinburgh Academy and the University of Edinburgh, where he graduated in 1921, after serving as a second lieutenant in the First World War. At that period it was natural for a graduate of a Scottish university with an interest in organic chemistry to turn his eyes towards St. Andrews, and, having been awarded a Carnegie Scholarship, Gulland went there to work under Prof. (later Sir) Robert Robinson, whom he rejoined in Manchester and again later in Oxford. Gulland became a University demonstrator in chemistry at Oxford in 1924, and was appointed lecturer in chemistry at Balliol College in 1926. These appointments he relinquished in 1931, when he became senior assistant in biochemistry at the Lister Institute, London, and a reader in biochemistry in the University of London. In 1936 Gulland was appointed to the Sir Jesse Boot Chair of Chemistry at University College, Nottingham, which post he resigned in September of this year in order to take up a new appointment as director of research to the Institute of Brewing. This position had been vacant since the death of Sir Gilbert Morgan in 1940, and in reviving the post the Institute of Brewing planned to expand its research activities and to set up its own central research laboratories. At the time of his death, Gulland had already begun to apply him. self with his customary vigour and enthusiasm to the execution of these plans. He was married in 1924, and is survived by his wife and two daughters.

Although he has a large amount of first-rate scientific achievement to his credit, Gulland was not quite so prolific a contributor to the original literature as some of his contemporaries. This is partly due to the formidable nature of the problems which he tackled; he never engaged in trivialities. It is probably due also to the fact that his earlier ardour for work at the bench tended to be subordinated later to his interest in organisation and administration, for which he had a real flair. He served on the councils of the Chemical Society and the Royal Institute of Chemistry, and was an honorary secretary of the Chemical Society during 1933-36. From 1932 until 1934 he was secretary of Section B of the British Association, and during 1935-37 he was recorder to the Section. During the early years of the Second World War he was senior gas adviser to the North Midland Region of the Ministry of Home Security, and during 1943-44 he was assistant director, Chemical Research and Development, Ministry of Supply. In this capacity he was attracted by the potentialities of alginic acid as a chemical raw material, and he took an important part in the establishment of the Scottish Seaweed Research 